\title{
HUKUM DAN KEKUASAAN
}

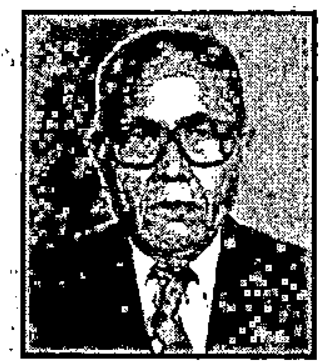

Imam Suhadi

Pasang-surut hubungan antara hukum dan kekuasaan dalam perjalanan negeri ini telah. menunjukkan menguatnya salah satu aspek dan melemahnya aspek lainnya, sangat terpengaruh oleh pemerintah negara. Maka suatu ketegasan sikap perlu ditempuh, jalah bahwa apabila ada "pergolakan" antara hukum dan kekuasaan, maka seharusnya hukum lah yang dimenangkan, demikian terungkap dari tulisan Imam Suhadi berikut ini.

\section{PENDAYULUAN}

\section{HUKUM DAN KEKUASAAM SELALU BERGANDENGAN}

Dalam tulisan saya dalam buku yang berjudul Cita-cita dan Kenyataan Demokrasi (Imam Suhadi 1981) saya mengemukakan thesis bahwa llmu Politik dan IImu Hukum berhubungan erat, bahkan tidak dapat dipisahkan. Keduanya mempelajari satu obyek materi ialah hubungan manusia dalam masyarakat bedanya ILmu Hukum mempelajari tingkah laku manusia dari aspek hak dan kewajiban sedang IImu Politik mempelajari tingkah laku manusia dari aspek kekuasaan.
Menurut keterangan di atas IImu Politik identik dengan kekuasaan sebab menurut Mariam Budiarjo dalam bukunya DasarDasar limu Politik menyatakan (Budiarjo 1993) politik adalah kegiatan dalam sistem politik yang menyangkut proses menentukan tujuan, pengambilan keputusan maka harus memiliki kekuasaan dan kewenangan dalam melaksanakan proses tersebut. Dengan kata lain politik identik dengan kekuasaan. Di bawah ini akan kami berikan contoh bahwa pemilihan umum dapat dilihat dari 
aspek kekuasaan (politik) dan dapat dilihat aspek hukum.

Dari aspek politik Pemilu adalah memilih wakil-wakil rakyat, wakil-wakil tersebut akan memilih Preșiden yang memegang kekuasaan dalam pemerintahan negara, dan. Pemilu dapat dilihat dari aspek hukum apakah dilaksanakan sesuai dengan undangundang Pemilu. Kekuasaan menurut Budiarjo (1993) ada-lah kemampuan seseorang untuk mempengaruhi tingkah laku orang lain. Kekuasaan adalah inti dari politik, seperti pendapat Robson dalam bukunya The University Teaching of Social Sciences, "Polical Science is Concerned with the study of power in Society. Its nature,basis,prosesses,scope and results".

\section{PANDANGAN AHL HUKUM TERHADAP PROSES POLITIK MENGATUR NEGARA.}

Pandangan ahli hukum terhadap proses politik (mengatur negara) terdapat dua aliran. Aliran pertama dipelopori oleh sarjana Austria Hans Kelsen yang terkenal dengan Mazhab Wina memiliki pandangan yuridis normatif, dengan "teori hukum murni"nya (Reine Rechts Lehre).

Hans Kelsen menganggap negara sebagai suatu badan hukum atau Rehts persoon yang mempunyai hak dan kewajiban, oleh karenanya problema negara harus diselesaikan dengan cara normatif. la menolak untuk memperhitungkan faktor sosiologis karena akan mengaburkan analisa yuridis. Negara adalah Badan Hukum tertinggi kecuali punya hak dan kewajiban juga berhak mengatur. Aliran ini sangat mengutamakan normatif dan selalu mencari unsur keadilan dan orientasinya. selalu. menuju negara : hukum (Rechtsstaat).

Aliran yang kedua yang dipelopori oleh Yellinek dan Herman Hellen yang terkenal dengan Mazhab Berlin berpendapat bahwa untuk memecahkan. problema kenegaraan kecuali pemecahan secara yuridis dan normatif juga harus memperhatikan faktor sosiologis terutama menganalisa negara-negara yang sedang berkembang dan mengalami perubahan sosial.

\section{PERHATIAK AHLI HUKUM TERHADAP HUKUM:DAK POLITIK}

Karena pentingnya hubungan hukum dan kekuasaan dan banyaknya masalah yang timbul, maka banyak ahli hukum yang mengadakan penelitian dan menulis masalah tersebut, antara lain Daniel $S$. Lev seorang sarjana Amerika yang belajar di Universitas Cornell mengadakan penelitian di Indonesia tentang hubungan hukum dan politik pada tahun 1959 dan hasil penelitiannya disusun sebagai bahan disertasi doktor pada almameternya Universitas Cornell pada tahun 1962 yang berjudul Hukum dan Politik di. Indonesia (terjemahan Bahasa Indonesia oleh Nirwono dan AE.Priyono).

Daniel $S$. Lev nampaknya ingin mengembalikan perhatian pada suatu pendekatan yang realistis dalam rangka memahami proses hukum sebagai bagian dari perubahan sosial dan politik di Indonesia atau masalah perubahan politik dan. pengaruhnya terhadap proses hukum di Indonesia.

Daniel S.Lev mengamati perubahan politik di Indonesia dari jaman kolonial, ke masa permulaan kemerdekaan sampai pada masa demokrasi 
terpimpin,serta pengaruhinya terhadap proses hukum di Indonesia. Pada waktu berlakunya demokrasi terpimpin peranan pengadilan dan hakim sangat menurun, bahkan pada suatu periode peranan dan pengaruh hakim sangat terdesak dan kalah dengan pengaruh jaksa dan kepolisian karena jaksa dan kepolisian mendapat dukungan kuat dari birokrasi. Idea unifikasi pengadilan dan unifikasi hukum di Indonesia karena pengaruh suasana politik di Indonesia yang bergolakk menuju negara kesatuan setelah membenci negara federal (RIS). Perubahan masyarakat karena dorongan dan tuntutạn organisasi advokat terutama Lembaga Bantuan Hukum (LBH) sangat mempengaruhi proses hukum di Indonesia dalam rangka penegakan hukum dan pelaksanaan hak asasi manusia.

Demikian - beberapa contoh perubahan proses hukum yang dipengaruhi oleh perubahan politik.

Dr. Moh:Mahfud MD. dalam tulisannya yang berjudul Demokrasi dan Konstitusi di Indonesia adalah penuh memuat pergolakan antara hukum dan kekuasaan yang diberi komentar oleh Dr. Afan Gaffar sebagai refleksi kegelisahan seorang sarjana hukum.

Dalam penutup tulisan tersebut Mahfud menulis bahwa perjalanan Orde Baru bergeser ke langgám otoritarisasi dengan langkahnya yang penetratif; apalagi setelah jendral Soeharto yang didukung militer dan Golkar sehingga menjadi negara kuat: Yang terakhir Mahfud mensinyalir intervensi negara kepada organisasi politik, kemasyarakatan untuk memperkuat daya kontrol, dan membatasi hak politik rakyat.

\section{PGONUUK DAH PEDOMAN UUD 1945 MEN GHADAPI PERGOLAKAN GUKUM Dah Kezuasaar.}

Pergolakan hukum dan kekuasaan biasanya cenderung bahwa kekuasaan yang di atas angin dan hukum menjadi terdesak dan tak berdaya seperti.yang ditulis Mahfud di atas.

Sesungguhnya di dalam UUD 1945 telah ada petunjuk dan batasan dan itulah pentingnya konstitusi artinya apabila terjadi pergolakan antara hukum dan kekuasaan yang lebih dominan, maka harus dikembalikan bahwa negara kita adalah negära hukum bukan negara kekuasaan belaka seperti pernah terjadi pada permulaan Orde Baru banyak tuntutan dari masyarakat yang menghendaki berlakunya The Rule of Law dengan kata lain menuntut diberlakukannya negara hukum. Terjadilah seminar-seminar yang menuntut berlakunya The Rule of Law atau berlakunya negara hukum di Indonesia. Timbul pertanyaan apa itu The Rule of Law?

\section{THE RUIE OF LAW}

Istilah The Rule of Law di Indonesia baru terkenal pada awal Orde Baru ialah pada waktu berakhirnya Orde Lama yang banyak mengadakan penyelewengan terhadap hukum seperti Presiden sebagai sumber hukum, mengangkat Presiden dengan masa jabatan seumur hidup. peraturan-peraturan (UU) tidak usah disetujui DPR tetapi cukup keputusan Presiden sendiri yang disebut Kepres, kekuasaan Presiden terhadap kekuasaan kehakiman dan lain-lain, maka timbullah. tuntutan dalam masyarakat agar diperlakukan The Rule of Law: 
Tetapi istilah The Rule of Law di Amerika Serikat, di Inggris dan negri Belanda telah lama dikenal. Hanya kalau di negeri Belanda disebut Rechsstaat. Sesungguhnya istilah tersebut sama dengan istilah di Indonesia "negara hukum".

Arti dan maksud istilah The Rule of Law telah mengalami perkembangan dan telah menjadi pembahasan para yuris atau ahli hukum dalam konferensinya yang bertaraf internasional seperti di Athena tahun 1955, di New Delhi tahun 1959, di Lagos, Nigeria tahun1961, di Rio de Jainero,Brasillia tahun 1962 dan terakhir di Bangkok tahun 1965. (lihat bukunya Sumaryati Hartono, apakah The Rule of Law itu ? 1976).

Dari sejarah perkembangan istilah tersebut mulai arti yang sederhana ialah segala sesuatu seharusnya serba teratur menurut aturan hukum melalui Konferensi Yuris Internasional (International Conference of Yurist atau disingkat I.C.Y:) The Rule of Law mempunyai arti yang lebih lengkap dan luas, ialah adanya sarat-sarat dasar terselenggaranya pemerintah yang demokratis dibawah Rule of Law, yaitu :

1. Perlindungan Konstitusional dalam arti perlindungan hak asasi manusia.

2. Pengadilan yang bebas (independent and impartial tribunals).

3. Pemilihan umum yang bebas.

4. Kebebasan menyatakan pendapat.

5. Kebebasan politik dan oposisi.

6. Pendidikan kewarganegaraan (civic education)

(Mariam Budiarjo 1993 hal 60)

Yang perlu dicatat disini adalah hasil simposium Fakultas Hukum Universitas di Indonesia 8 Mei 1966 setelah ada gejolak dan turitutan berlakunya The Rule of Law di Indonesia. lain :

Kesimpulan simposium tèrsebut antara

I. Negara Indonesia adalah suatu negara hukum yang berdasarkan Pancasila.

II. Ciri-ciri khas bagi Negara Hukum adalah :

1. Pengakuan dan perlindungan hakhak asasi yang mengandung persamaan dalam bidang politik, hukum,sosial, ekonomi, kultural dan pendidikan.

2. Peradilan yang bebas dan tidak memihak.

3. Legalita, dalam arti hukum dalam semua bentuknya.

\section{NEGARA HUKUM SEBAGAI PILIHAH}

Sebagai kesimpulan tulisan ini kami kemukakan, bahwa apabila ada pergolakan antara hukum dan kékuasaan, maka seharusnya hukum . yang dimenangkan. Negara kita sebagai negara hukum dimana hukum memiliki supermasi maka hukumlah diatas segala-galanya, negara atau pemerintah harus tunduk pada hukum, bukan sebaliknya hukum tunduk atau dikalahkan oleh kekuasaan.

Lebih jelasnya di bawah ini kami sajikan dua pakar hukum Indonesia yang menguraikan negara hukum hubungannya dengan Rule of Law ialah Ismail Suny dalam bukunya Mekanisme Demokrasi Pancasila, kedua Sunaryati Hartono dalam bukunya apakah itu The Rule of Law?.

Ismail Suny uraiannya pada seminar Hukum Nasional di Semarang 30 Desember 1968 menyatakan negara 
hukum merupakan syarat adanya mekanisme Demokrasi Pancasila. Negara Indonesia adalah negara hukum berdasarkan UUD 1945 baik dalam pembukaan, Batang Tubuh dan Penjelasan UUD 1945.

Dalam pembukaan UUD 1945 disebut "peri keadilan" merupakan indikasi pengertian negara hukum. Dalam Batang Tubuh UUD 1945 disebut " maka disusunlah Kemerdekaan Kebangsaan Indonesia dalam satu UUD", merupakan indikasi konstitusional (di dalam penjelasan UUD 1945 dengan tegas disebutkan; bahwa Negara Indonesia adalah Negara Hukum (Rechsstaat) bukan negara kekuasaan belaka (Machsstaat).

Menurut Ismail Suny Negara Indonesia adalah Negara Demokrasi suatu negara hukum atas jaminan Rule of Law sebagai lawan Rụle by Decre dibawah sistem otoriter. Negara hukum harus terdapat kondisi minimum dimana hak asasi manusia dan human dignity dihormati seperti keputusan Congres International Commission of Yuris di Athena tahun 1955.

Hak Asasi manusia dan human dignity tersebut meliputi :

1. Keamanan pribadi harus dijamin. Ták seorangpun dapat ditahan atau dipenjarakan tanpa keputusan hakim. Tempat kediaman tak dapat dilanggar; tak seorangpun dapat dideportasi, "diasingkan kecuali dengan keputusan hakim, didasarkan ketentuan hukum.

2. Tidak ada hak-hak fondamentil yang dapat ditiadakan seperti hak menyatakan pendapat. Tidak boleh ada paksaan pendapat yang berbeda dengan keyakinañnya.
3. Setiap orang dijamin kebebasan pendapat melalui media komunikasi, termasuk kebebasan menerima informasi, tidak boleh adanya sensor dan campur tangan penyajian;

4. Rahasia surat harus dijamin, tidak boleh mencampuri urusan pribadi orang lain.

5. Kebebasan agama harus dijamin, setiap kepercayaan yang diakui harus dihormati.

6. Terjaminnya mendapatkan pendidikan dan pengajaran termasuk pengajaran di universitas.

7. Kebebasan politik harus terjamin.

8. Setiap orang dijamin hak politiknya dalam pemithihan umum yang bebas, rahasia, jujur dan adil.

9. Kekuasaan penguasa adalah pencerminan kemauan rakyat, hak mencalonkan pemimpin adalah hak rakyat.

10.Dijamin kebebasan pengadilan.

11.Menghormati hak-hak minoritas.

Sunaryati Hartono dalam bukunya "Apakah The Rule of Law itu ". dengan melihat sejarah perkembangan istilah itu di Amerika Serikat, di Inggris dan Negeri Belanda, dapat diambil kesimpulan, bahwa Negara Hukum sangat erat dengan The Rule of Law, maka negara melaksanakan hukum yang adil (just law) dengan -menjamin hak-hak asasi manusia, dan apabila terjadi penyelewengan dan penyalah - gunaan kekuasaan dari penguasa, pihak perigadilan berhak mengadili. Menegakkan The Rule of Law / Negara Hukum adalah :

1. Membawa misi keadilan dalam pelaksanaan hukum atau keadilan 
sosial / dalam arti materiil, tidak formalistis dan hanya legalistis, tetapi berpijak asas kebenaran dan keadilan.

2. Mengangkat.fungsi Mahkamah Agung, pengadilan pada umumnya dan hakim pada khususnya untuk menguji undangundang atau kebijaksanaan pemerintah (penguasa), apakah peraturan perundang-undangan telah sesuai dengan cita-cita negara atau apakah ada penyelewengan atau penyalahgunaan kekuasaan oleh penguasa dalam melaksanakan wewenangnya.

3. Perlu adanya sistem Herziening atau "Peninjauan Kembali" terhadap keputusan hakim (Mahkamah Agung) untuk menampung kemungkinan adanya "Rechts-dwalingen" atau "kesesatan hukum".

\section{DAFTAR PUSTAKa}

Daniel S Lev, Hukum dan Politik di Indonesia, LP3ES, 1990 Jakarta.

Mariam Budiarjo, Dasar-Dasar IImu Politik, Gramedia, 1993, Jakarta.

Ismail Suny, Mekanisme Demokrasi Pancasila, 1987, Aksara Baru Jakarta.
Moh. Mahfud MD. Dr., Demokrasi dan Konstitusi di Indonesia, 1993, Liberty, Yogyakarta.

Imam Suhadi, Cita-cita dan Kenyataan Demokrasi, 1981, Yogyakarta, Faskultas Hukum UII.

") Dr. H. Imam Suhadi, SH, adalah alumnus FH. UII Yogyakarta, kini selain sebagai dosen tetap pada FH. UII Yogyakarta dan Pembina Magister Hukum Ull Yogyakarta, juga mengajar di Institut Pendidikan Darussalam Gontor, Ponorogo. 